\title{
Cichlid biogeography: comment and review
}

\author{
Prosanta Chakrabarty
}

Museum of Zoology, Fish Division, University of Michigan, Ann Arbor 48109, MI, USA

\begin{abstract}
Phylogenetic analyses dealing with disjunct distributions (distributions that require marine dispersal or vicariant events) are reviewed for the Cichlidae. The most corroborated relationship between clades across a Gondwanan disjunction is the sister relationship between Indian and Malagasy cichlids. The minimum age of the Cichlidae as implied by the fossil record is at odds with the timing of the Cretaceous break of the Indian-Madagascar landmass. All well sampled phylogenies for this group fit a pattern reflecting Gondwanan break-up. Grounds for strictly dispersalist hypotheses are not well founded for any cichlid disjunct distribution, leaving vicariance alternatives as the only explanation.
\end{abstract}

Keywords Cichlidae, Gondwana, historical biogeography, vicariance

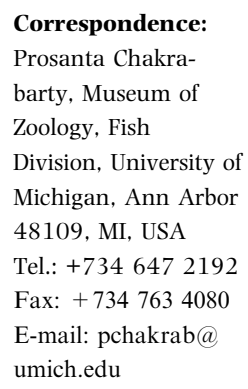

$\begin{array}{lr}\text { Introduction } & \mathbf{9 8} \\ \text { Cichlid biogeography: overview of the debate } & 98 \\ \text { Selecting among biogeographical hypotheses } & 98 \\ \text { Cichlids on Gondwana } & 100 \\ \text { Alternative Plate Tectonic reconstructions for Gondwanaland breakup } & 100 \\ \text { Proposed relationships } & 101 \\ \quad \text { Monophyletic groups on Gondwanan fragments } & 101 \\ \text { Paraphyletic groups on Gondwanan fragments } & 102 \\ \text { Molecular clock evidence } & 106 \\ \text { India-Madagascar sister relationship } & \mathbf{1 0 7} \\ \text { Geological history } & 107 \\ \text { Vicariance } & 107 \\ \text { The Greater Antilles } & \mathbf{1 0 7} \\ \text { Antillean cichlids } & 108 \\ \text { Phylogenetic relationships } & 108 \\ \text { The Middle East, Europe and adjacent areas } & \mathbf{1 0 9} \\ \text { Current distribution and sister relations } & 109 \\ \text { Fossils from the area } & 110 \\ \text { The global cichlid fossil record } & \mathbf{1 1 1} \\ \text { Minimum ages } & 111 \\ \text { The acanthomorph record } & 111 \\ \text { Discussion } & \mathbf{1 1 3}\end{array}$ 
'Biogeography, if it is a science, must be able to predict pattern from pattern, and estimate process from pattern.' Savage (1982).

\section{Introduction}

The Cichlidae is a species-rich monophyletic group of brackish and freshwater perciform fishes. More than 1300 valid species are currently recognized, although estimates above 2000 total species are not uncommon (Kullander 1998). The distribution of this family has led to numerous hypotheses about the age and historical biogeography of this group. Improved techniques in molecular systematics and the discovery of the oldest known fossil cichlids during the past few years have led to a resurgence of debate about the historical biogeography of the group (Kumazawa et al. 2000; Murray 2001b; Vences et al. 2001; Sparks 2003). This study will review the evidence supporting scenarios explaining cichlid distributions to determine if hypotheses of vicariance can be eliminated in favour of a marine dispersal hypothesis.

\section{Cichlid biogeography: overview of the debate}

Cichlids are widely distributed in southern continental regions including South and Middle America (400 species), Cuba and Hispaniola (four species), Africa (>1000 species), Madagascar ( $>18$ species), Arabia and adjacent areas (Israel, Syria, Iran) (five species) and India (three species) (Fig. 1). This distribution pattern has led researchers to propose an Early Cretaceous origin for the assemblage (Rosen 1975; Stiassny 1991). This period (120$130 \mathrm{Ma})$ constitutes the period of fragmentation of the southern super-continent, Gondwana. Cichlids are also found on non-Gondwanan fragments, including Europe (as fossils) and the Greater Antilles.

The oldest fossil cichlids date back only to the Eocene (54-38 Ma; Murray 2000a, 2000b, 2001a). Some researchers have argued that dispersal across marine environments, rather than drift vicariance (vicariance because of continental drift), is more likely given evidence from the fossil record, molecular clock estimates of divergence, and the salt tolerance of some extant cichlids (Briggs 1984; Murray 2001b; Vences et al. 2001). Vicariance biogeographers emphasize the derived nature of the earliest fossil cichlids, and the lack of evidence for intercontinental marine dispersal (Stiassny 1991; Sparks 2003). Both sides have used phylogenetic analyses to support their claims.

The monophyly of the Cichlidae is supported by morphological (Zihler 1982; Gaemers 1984; Stiassny 1991) and molecular evidence (Streelman and Karl 1997; Farias et al. 1999, 2000). Despite recent phylogenetic work, the sister group of cichlids remains unknown (Stiassny \& Jensen 1987; Zardoya et al. 1996; Streelman and Karl 1997). Researchers currently agree that one of the groups traditionally placed within Labroidei (possibly an unnatural group; Streelman and Karl 1997) is the sister group to cichlids. Besides cichlids, Labroidei includes three other families: surfperches (Embiotocidae), damselfishes (Pomacentridae), and wrasses and parrotfishes (Labridae).

As all Labroidei except cichlids and a single embiotocid (Nelson 1984) are strictly marine, the sister group of cichlids is probably marine, and a marine ancestor for the family is plausible. Most cichlids are restricted to freshwater habitats, but there are cases of cichlids living in brackish habitats or being found swimming in marine waters (see examples in Murray 2001b). Certainly, to some cichlid species a marine habitat is hospitable. However, as there are no known instances of cichlids crossing a marine environment by dispersing from one landmass to another, the marine environment may still be considered a barrier to dispersal.

\section{Selecting among biogeographical hypotheses}

There are many methods that have been proposed for selecting between biogeographical hypotheses (see Crisci 2001). I adopt a cladistic biogeographical approach sensu Rosen (1985) and Nelson and Platnick (1981). This method was selected over others because it uses area cladograms that can be created from the published phylogenies reviewed here. This method was also selected over others because it is the only one that utilizes the principle of parsimony, 


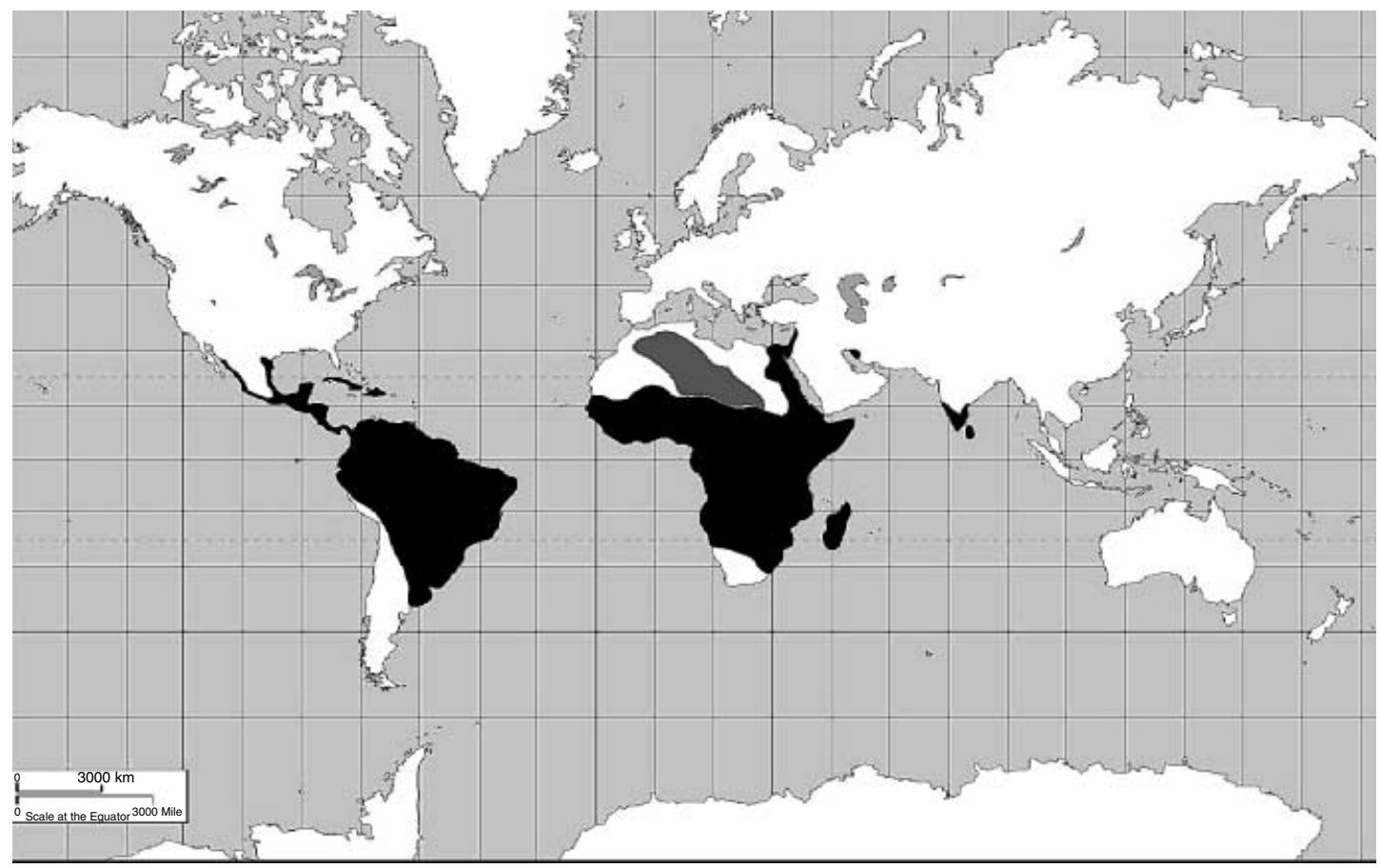

Figure 1 Cichlid worldwide distribution from Sparks (2001).

which by minimizing assumptions finds the most efficient explanation of the evidence (Sober 1988).

The cladistic biogeographical approach assumes a shared correspondence between phylogenetic history and geological history. The relationship between these histories can be seen in congruent patterns of different taxonomic and area cladograms (cladograms with taxon names replaced by distributions) fitting a given pattern of geological history. In this method, dispersal is assumed not to explain a disjunct distribution until vicariance can be falsified (Croizat et al. 1974; Kluge 1989). Vicariance is a simpler interpretation than dispersal for congruent area cladograms of different taxa, because the congruence can be explained by a single event (i.e. the rifting of a continent or orogeny). The same interpretation of distributions by dispersal would require concordant dispersal in the same sequence for many diverse taxa (Figs 2 and 3).

The essence of vicariance biogeography is that barriers arise secondarily to divide up species. Vicariance events, because they are tied to earth history, can only be supported by a very limited range of phylogenetic patterns. Dispersal scenarios, because they can occur without any underlying congruent process, can be claimed to support an unlimited range of phylogenetic patterns.

Area cladograms that fit a hypothesized geographical fragmentation sequence may support vicariance, or at least do not falsify it. All distribution patterns can be explained by dispersal. Dispersal scenarios therefore should not be employed unless vicariance scenarios have been falsified.

Vicariance scenarios for freshwater fishes have the following potential falsifiers: (i) the phylogenetic pattern (sequence of lineage divergence) does not follow the timing of known geological processes (i.e. the sequence of fragmentation) (Fig. 3), (ii) members of particular lineages are younger than hypothesized related vicariance events, (iii) a species of the group under study is found on either side of a supposed barrier to dispersal, (iv) molecular clocks or sequence divergence times reliably show that lineages have diverged after the particular vicariant events under study.

Dispersal will be the favoured mechanism to explain a disjunct distribution when falsifiers of vicariance - by adding assumptions to a vicariance hypothesis - make dispersal a simpler alternative. The possibility also exists that the current evidence 

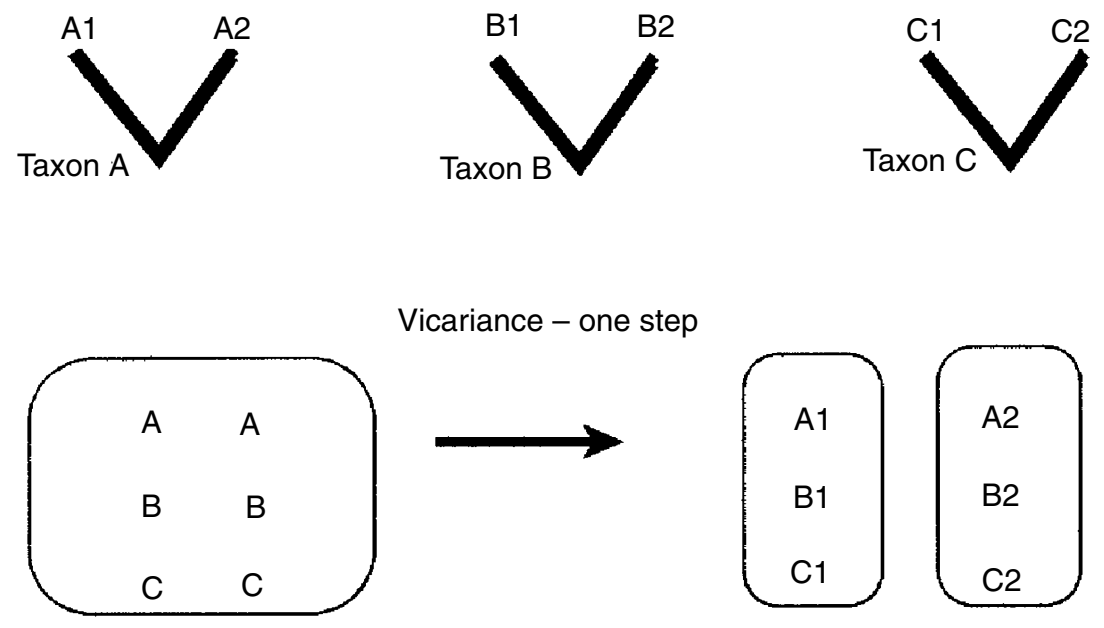

Dispersal - three steps

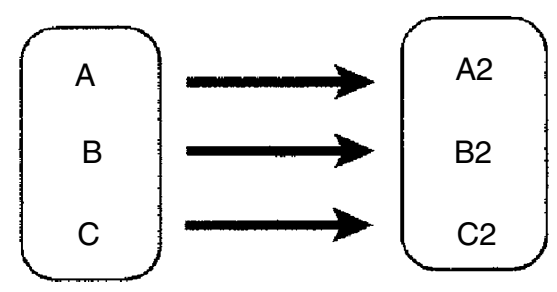

Figure 2 Congruent cladograms for three hypothetical taxa. The most parsimonious explanation would be a single vicariance event rather than multiple independent and sequentially concordant dispersal events.

is insufficient to select between alternative explanations of disjunct distributions.

\section{Cichlids on Gondwana}

If cichlids were present on Gondwana before its breakup, the minimum age of the family would be at the end of the Early Cretaceous (120 Myr). There is general agreement that the timing of the breakup of Gondwana occurred around this time (Hay et al. 1999; see below). What is not clear is the sequence of fragmentation. Reconstructions of this sequence are essential to forming congruent patterns of area cladograms following a specific scenario of Gondwanan breakup.

\section{Alternative Plate Tectonic reconstructions for Gondwanaland breakup}

There are two major plate tectonic reconstructions for the Cretaceous. Until recently there was a consensus that by 120 Myr, South America, Africa, India, Australia and Antarctica had separated from one another and deep ocean passages lay between them (Dietz and Holden 1970; Smith et al. 1973; Briden et al. 1974; Zonenshain et al. 1984; Barron 1987; Scotese 1991). In this scenario, the sequence of separation relevant to this discussion begins with the India/Madagascar block separating from Africa/ South America, followed by the subsequent separation of India from Madagascar and then Africa from South America. Biologists questioned this 'classical reconstruction' because of a number of sister group relations for taxa that likely could not cross some of the implied barriers. A recent re-examination of continental margins using seismic profiling and sea floor magnetic lineations has revealed an alternative tectonic reconstruction (Hay et al. 1999). In the Hay et al. scenario, Africa separates from a single continental block consisting of South America-Antarctica-Madagascar-IndiaAustralia in the Early Cretaceous (120-130 Ma). 
Actual geological sequence of fragmentation

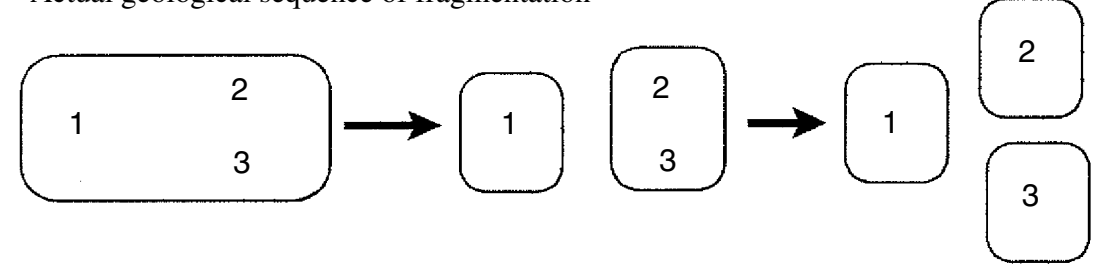

Area cladogram and implied sequence of fragmentation
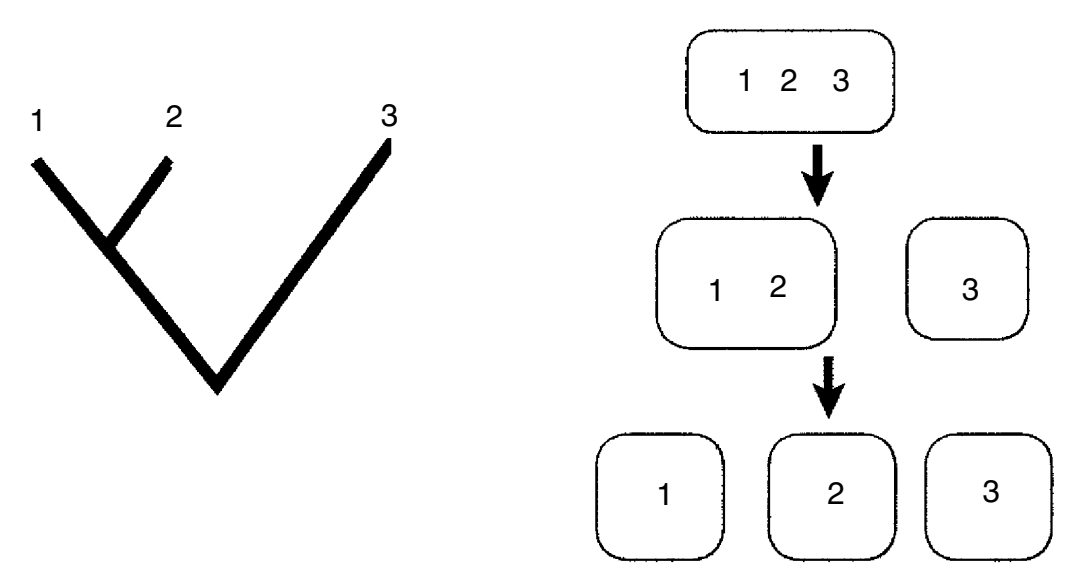

Figure 3 A demonstration showing how lineage divergence sequences can be incongruent with timing of known geological processes. Numbers indicate areas, not species.

This large continental block remained intact until the Late Cretaceous (80-90 Ma). The consequence of this scenario is that members of this continental block had a closer connection with each other for 30-60 Myr longer than they did with Africa (Fig. 4). These alternative scenarios will have important consequences on how different phylogenetic relations of cichlids fit with a vicariance or marine dispersal scenario.

\section{Proposed relationships}

In order to use a cladistic biogeographical approach, a cichlid phylogeny must be recovered before congruent cladograms from other taxa can be used to corroborate a hypothesis. However, there have been many proposed phylogenetic reconstructions for the family Cichlidae. This review will include all those recovered by cladistic analyses and that include multiple disjunct areas. Figure 5 includes all those that found monophyletic groups on Gondwanan fragments or those with monophyletic fragments except Madagascar. Madagascar appears paraphyletic in all analyses that include the genus Paretroplus from Madagascar and Etroplus from India with other Malagasy taxa. These two genera have been found as sister lineages in every analysis that has included them.

Figure 6 includes all analyses that have one or more paraphyletic Gondwanan fragments (besides Madagascar). Figure 7 shows the two most extreme hypothetical area cladograms from those in Figs 5 and 6 , illustrating what these clear alternatives would be able to suggest.

\section{Monophyletic groups on Gondwanan fragments}

It could be argued that monophyletic groups on all former Gondwanan landmasses would make a strong case for vicariance (Fig. 7a). This situation appears in Schliewen and Stiassny (2003) (Fig. 5b); Farias et al. (2000) (Fig. 5c and d), and Streelman et al. (1998) (Fig. 5c). However, each of these phylogenies lacks a paraphyletic Malagasy lineage presumably because the authors did not sample Paretroplus and Etroplus. Paraphyly of the Madagascan cichlids does not rule out a vicariance scenario, 
(a) $100 \mathrm{Ma}$

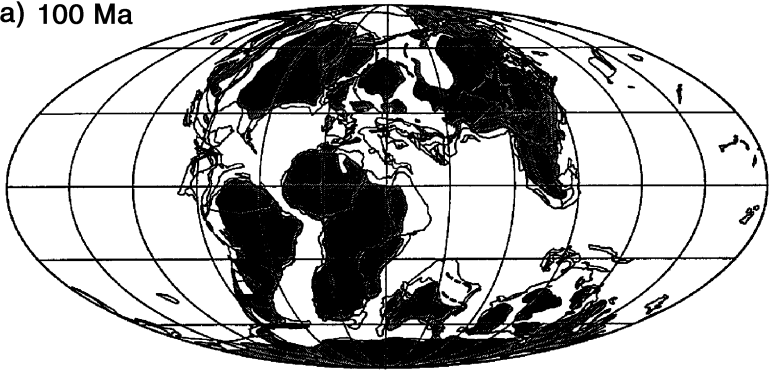

(b) $100 \mathrm{Ma}$

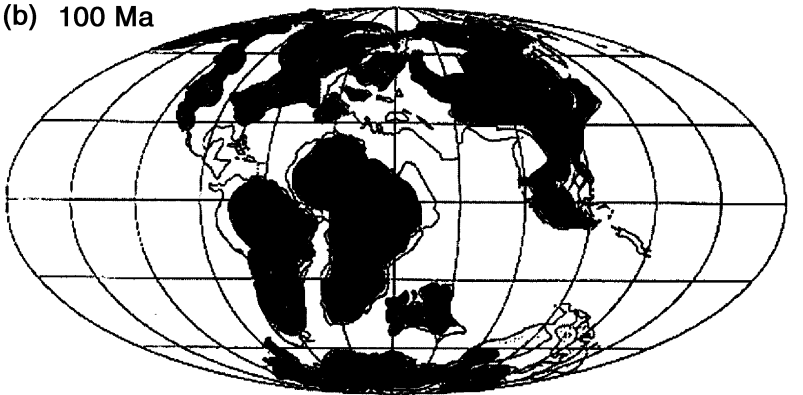

Figure 4 Early Cretaceous tectonic reconstructions of (a) Hay et al. 1999 and (b) 'classical' reconstruction. in fact it may be the strongest case for vicariance (see 'India-Madagascar sister relationship').

The analyses that recover monophyletic African and South American lineages as sister groups are significant because of congruence with other taxa (Zardoya et al. 1996; Streelman et al. 1998; Farias et al. 1999, 2000; Schliewen and Stiassny 2003; Sparks 2003; in Fig. 5b-g). Freshwater fishes with area cladograms congruent with cichlids (in showing sister relationships between South America and Africa rather than with a lineage on another continent) include: lungfishes (Lepidosiren and Protopterus), osteoglossids (Arapaima and Heterotis), nandids, aplocheiloid cyprinodontiforms, galaxiids and synbranchids (Rosen 1975; Lundberg 1993; Lundberg et al. 2000). These freshwater species would hypothetically have the same requirements as cichlids for dispersal. This scenario also fits the 'classical' reconstruction of Gondwanan fragmentation, as this scenario favours an Africa-South America sister group relationship over a South America-Antarctica-Madagascar-India-Australia connection.

Paraphyletic groups on Gondwanan fragments

Figures 6a-g (see also Fig. 7b) shows paraphyletic groups on one or more Gondwanan fragments other than Madagascar. All these are caused by one of three taxa, Heterochromis multidens, Oxylapia polleni or Chaetobranchopsis australis.

Heterochromis multidens, a monotypic African taxon, appears to be a difficult species to code in morphological analyses. Stiassny (1991) (Fig. 6e) found that this species might be sister to the etroplines (Etroplus of India and Paretroplus of Madagascar). Kullander (1998) (Fig. 6g) recovered this species as nested within his otherwise monophyletic Neotropical assemblage. Oliver (1984)

Figure 5 Diversity of phylogenetic trees with monophyletic groups on Gondwanan fragments or with a paraphyletic Madagascar. All trees that include species from the genus Paretroplus (Madagascar) and Etroplus (India) find a sister relationship between them that makes Madagascar paraphyletic when other Malagasy taxa are included. (a) Sparks (2001), parsimony using morphology, CO1, and 16S; *The positions of Africa and the Neotropics are switched and morphology when morphological characters are excluded from this data set Sparks 2003 (b) Schliewen and Stiassny (2003) Parsimony using Tmo27, Tmo4C4, DXTU, (c) Farias et al. (2000), minimum evolution tree 16S \& TmoM27, Tmo4C4 and Farias et al. (2000), parsimony, TmoM27 \& Tmo4C4 Streelman et al. (1998), 'neighbor joining bootstrap consensus', Tmo4C4 \& TmoM27 (d) Farias et al. (2000), total evidence tree 16S \& TmoM27, Tmo4C4 \& morphology from Kullander (1998) (e) Zardoya et al. (1996) "50\% majority rule bootstrap neighbor joining consensus tree" using TmoM27 Farias et al. (2000) Minimum evolution, using 16S rRNA (f) Zardoya et al. (1996) parsimony Tmo-M27 Streelman et al. (1998) parsimony, TmoM27, Tmo4C4 (g) Farias et al. (1999); Sparks (2003) Parsimony, 16S rRNA (h) Cichocki (1976), clique analysis, morphological characters Madagascar assumed 'basal'. 

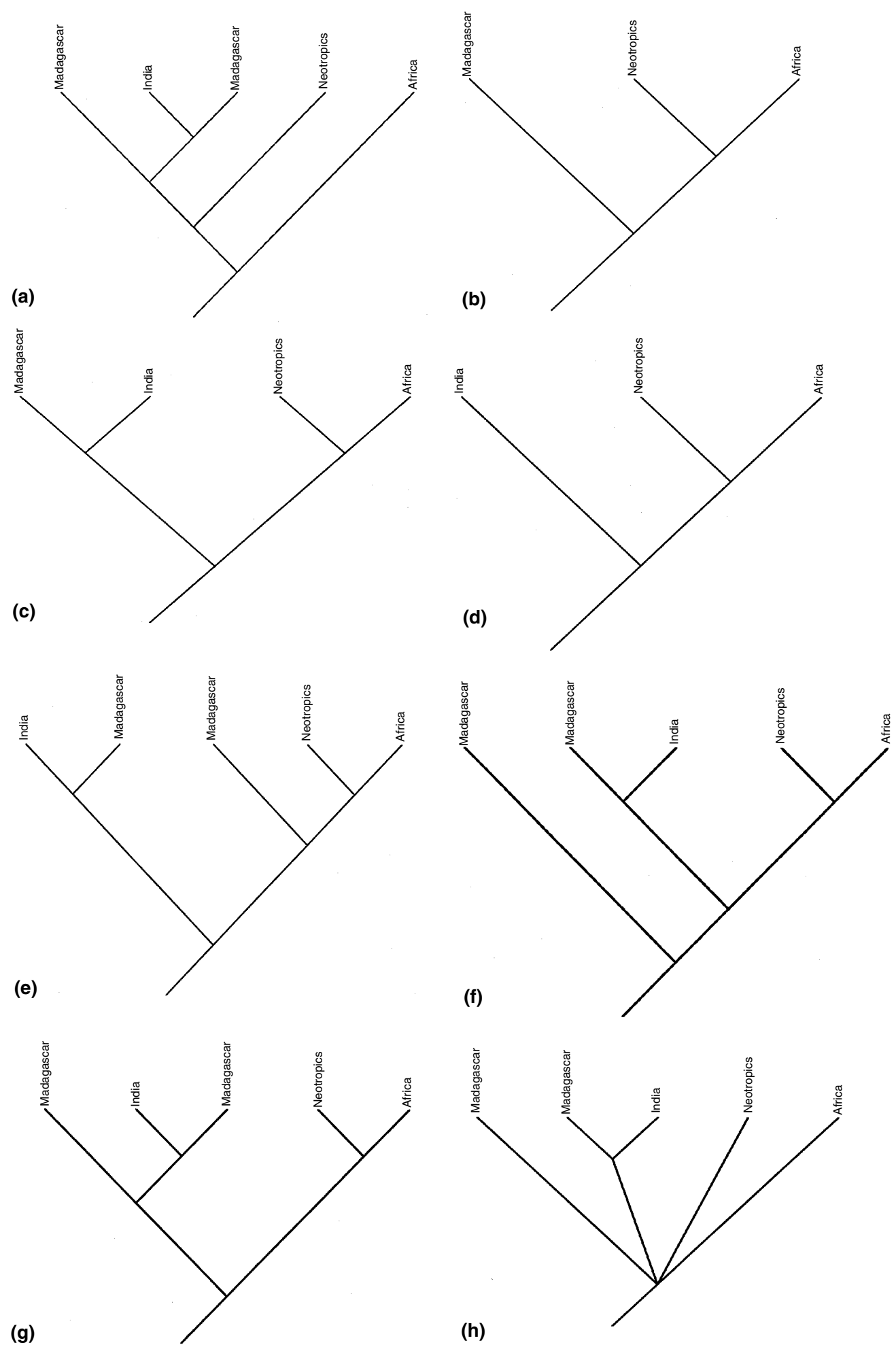

(Fig. 6f) also recovered this species as closely related to the South American genus Cichla, which together with Heterochromis was excluded from both the

Neotropical and African assemblages. These three analyses borrowed many components from Cichocki's (1976) (Fig. 5h) non-cladistic character 


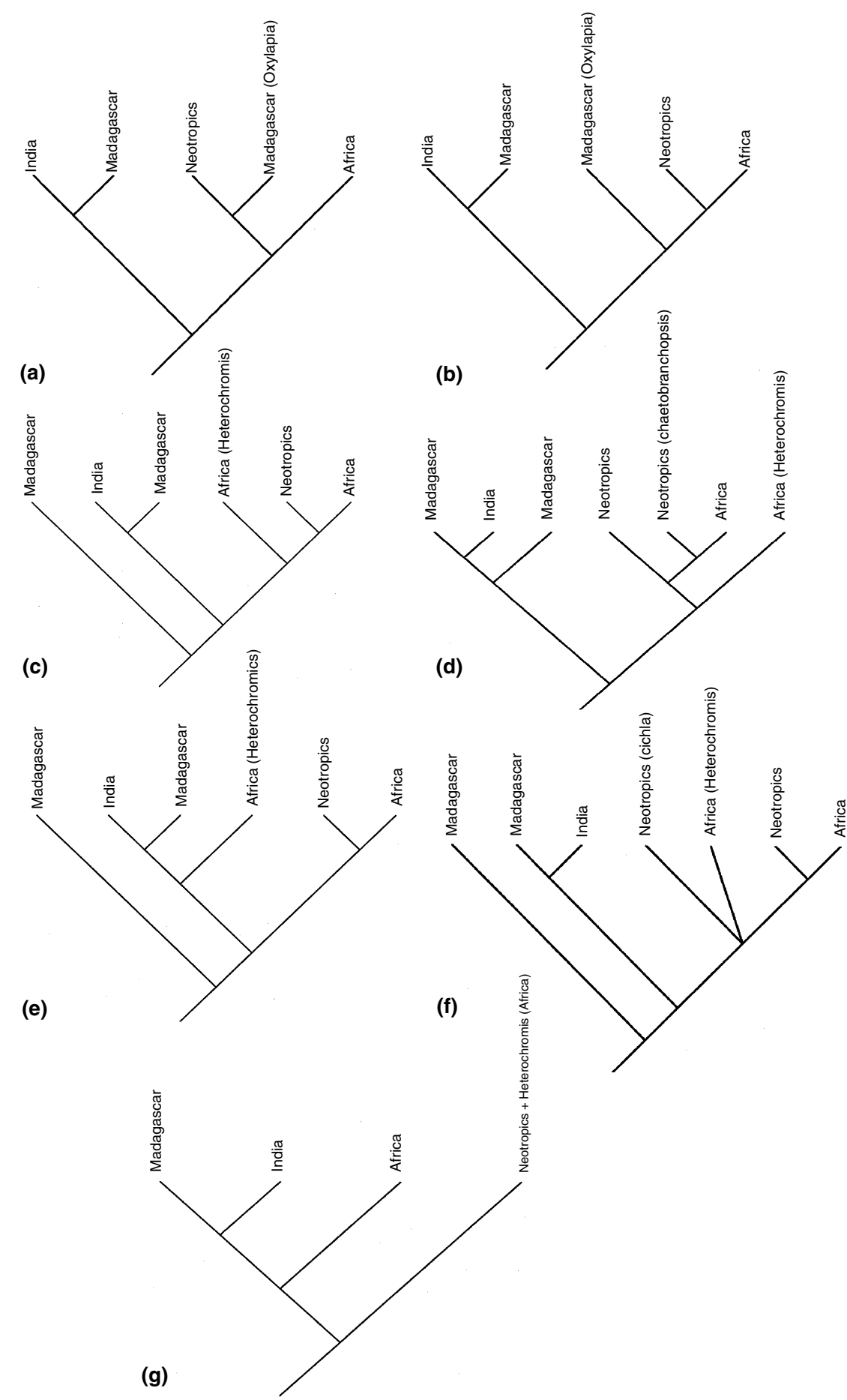

Figure 6 Diversity of phylogenetic trees with paraphyletic groups on Gondwanan fragments. (a) Streelman and Karl (1997); Streelman et al. (1998), Neighbour joining from maximum likelihood distances, Tmo4C4 (b) Streelman and Karl (1997) Parsimony, Tmo-4C4 (c) Murray (2001b) a composite tree (from Stiassny 1991; Meyer et al. 1994; Lippitsch 1995. Nishida 1991;Lippitsch (1995) parsimony, scale and squamtion characters (d) Sparks (2001) parsimony using morphology (e) Stiassny (1991) parsimony using morphology based on Cichocki 1976 characters (f) Oliver (1984), parsimony tree based on Cichocki 1976, morphological characters (g) Kullander 1998, parsimony using morphology. 
analysis, which did not include Heterochromis. Lippitsch (1995) (Fig. 6c) also found a paraphyletic African lineage because of the exclusion of Heterochromis, which was placed as the sister taxon to the Neotropical and African assemblages. This phylogeny was based entirely on scale and squamation characters, characters that are often not useful in higher-level phylogenetic analyses because of their potentially homoplasious behaviour and non-independence. These scenarios suggest dispersal from Madagascar to Africa or from South America to Africa for Heterochromis. A pre-rifting divergence of this species and its ancestor would also leave this phylogenetic pattern (see Discussion).

Murray's (2001b) (Fig. 6c) composite tree is from Nishida's (1991) and Meyer et al.'s (1994) phylogenies of African cichlids, Lippitsch's (1995) scale and squamation phylogeny and Stiassny's (1991) morphological analysis of Cichlidae. From Murray's sample, only Lippitsch (1995) and Stiassny (1991) had cladograms that included the worldwide distribution of cichlids. The phylogenies of Nishida (1991) and Meyer et al. (1994) focused only on African cichlids. As the purpose of Murray's analysis was to show that marine dispersal is the most parsimonious conclusion for the historical distribution of cichlids, it would have been more appropriate to include all other analyses dealing with cichlid disjunct distributions.

Molecular analyses that included $H$. multidens find either that this species is nested within the African assemblage or sister to the rest of the African assemblage, recovering a monophyletic African assemblage in either case (Sültmann et al. 1995; Farias et al. 1999, 2000; Schliewen and Stiassny 2003; Sparks 2003). Morphological analyses may recover this species in non-African lineages because of its lack of obvious synapomorphic features.

Oxylapia, a monotypic Malagasy genus, was recovered as sister to the Neotropical assemblage in a neighbour-joining tree using a nuclear fragment (Tmo4C4) (Streelman and Karl 1997; Streelman et al. 1998) (Fig. 6a). In a parsimony analysis using the same fragment, it was found sister to the Neotropical and African assemblages (Streelman and Karl 1997) (Fig. 6b). This species is found nested within the Malagasy/Indian clade, when Malagasy genera other than Paretroplus are included (Stiassny 1991; Farias et al. 1999, 2000; Sparks and Reinthal 2001; Sparks 2003). Therefore, the position of Oxylapia in Streelman et al.
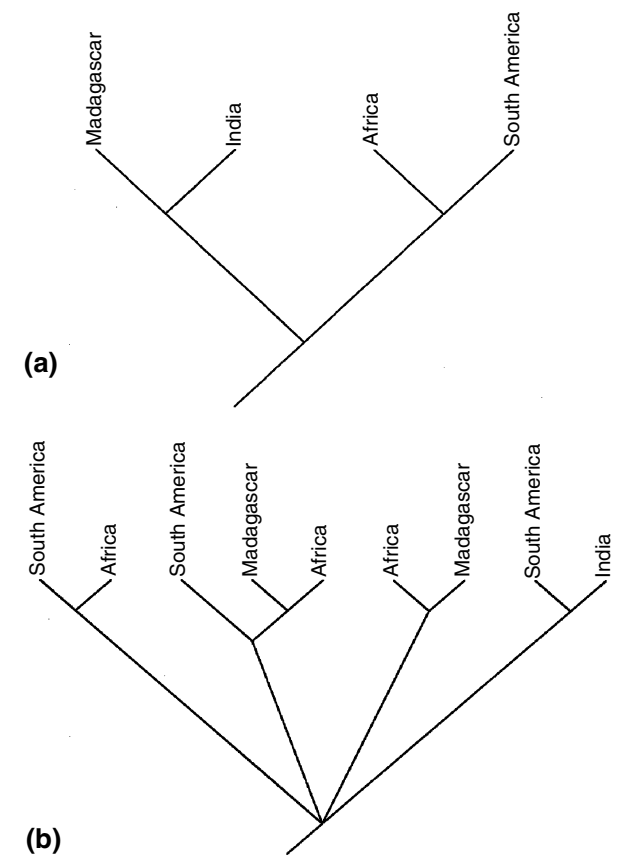

Figure 7 Examples of (a) Monophyletic continental groups, (b) Paraphyletic continental groups. (a) The consequence of monophyletic lineages on continental fragments (fragments assumed once to be part of a larger whole) are that the following possibilities exist to explain a given disjunct distribution: (i) vicariance by continental drift (as long as the sequence of divergence follows the proposed timing of fragmentation (ii) single dispersal events from one continent to another, without any subsequent successful dispersals (iii) multiple successful dispersals, followed by a extinction events that left the following pattern (reciprocal monophyly); and (iv) widespread ancestor (in the case of cichlids a marine ancestor) post fragmentation, gave rise to lineages on separate regions, that subsequently speciated forming clades; (b) The consequence of paraphyletic lineages for cichlids on former Gondwanan fragments, are that the following possibilities exist to explain a given disjunct distribution: (i) multiple successful dispersal events; and (ii) wide spread dispersal on the Gondwanan continent that led to a paraphyletic pattern, followed by fragmentation without subsequent extinctions (that led to a pattern of monophyly).

(1998) and Streelman and Karl (1997) can be explained by the exclusion of all Malagasy taxa save Paretroplus.

Streelman et al. (1998), present a consensus tree from their nuclear DNA analysis, which does not include Oxylapia. This is notable because its exclusion from the consensus is because of it not having been sampled using nuclear fragment TmoM27 although this taxon was used in the same paper 
with Tmo4C4 (another nuclear fragment). This consensus tree (shown in Fig. 5c) misleadingly implies that they recover a Malagasy/Indian clade in each of the separate analyses. Farias et al. (2000) also does not include Oxylapia despite using this genus in other molecular analyses in the same paper. Streelman et al. (1998) and Streelman and Karl (1997) also use a very misleading approach in labelling their area cladogram. In both the trees listed in Fig. 6a, the authors have Oxylapia sister to the Neotropical clades, making a paraphyletic India/ Madagascar lineage, but the authors show an area cladogram that depicts a monophyletic India/Madagascar lineage.

Sparks (2001) found a paraphyletic Neotropical assemblage in his morphological analysis because Chaetobranchopsis australis, a species from Paraguay, was found to be the sister group to a monophyletic African assemblage (nesting Africa within the Neotropical assemblage; Fig. 6d). Unfortunately his molecular trees and combined molecular and morphological data tree did not include this species.

The paraphyly of different groups in these analyses (Fig. 6a-g) can be attributed mainly to geographically biased sampling. Incomplete sampling has led to hypotheses of relationships that do not appear in better sampled analyses. Therefore their results of the biogeographical conclusions based on these analyses must be called into question.

\section{Molecular clock evidence}

Molecular data have a potential advantage over morphological data in that some molecules or molecular fragments may change at a near constant rate for a given period of time. The 'phylometric approach' or 'phylogeography' (Avise et al. 1987) recognizes that sequence differences (sometimes called 'genetic distances') among taxa contain information about both phylogenetic relationships and the timing of separation between lineages (Grant and Leslie 2001). To work, the rate at which the molecule or fragment is said to change must be correct, and the timing of the geological event that this clock is calibrated upon must also be correct.

Two molecular clock analyses using cichlids have been published. The first (Kumazawa et al. 2000) supports vicariance, but because of its small sample size, ambiguous results and circular reasoning, its conclusions may be questionable. The second analysis, Vences et al. (2001) fails in several ways.

Applying a molecular clock hypothesis, Vences et al. (2001) argued that dispersal was more likely than vicariance to account for the distribution of cichlids. The authors tested their hypothesis using a molecular clock based on 16s rRNA gene and a Tmo-4C4 nuclear fragment.

The authors use East African Rift Lake cichlids to calibrate a molecular clock. The ages of these lakes are imprecisely known; estimates range from 1 to 0.012 Myr, for Lake Victoria and for Lake Tanganyika from 4 to 12 Myr (Barlow 2000; Vences et al. 2001). Several authors have noted the paradox that the cichlid lineage of Lake Victoria is supposedly 250 000-750 000 years old, whereas geological evidence suggests that the basin of the lake dried out completely only 12 000-15000 years ago (Johnson et al. 1996; Nagl et al. 2000; Fryer 2001). These wide estimates of ages for the lakes, and the fact that the lineages within the lakes may not be the same age as the lakes themselves (Meyer et al. 1991; Nishida 1991), make this molecular clock calibration suspect. A more conservative calibration based on lake level fluctuations and in discussions of the rift lake cichlids alone (as carried out in other studies) is more reasonable (see Sturmbauer et al. 2001).

Vences et al. (2001) also found both molecular fragments failed to show clock-like evolution, as they were significantly rejected by the likelihood ratio test. Nevertheless, in order to use these data, the authors only used lineages that fit the particular clock for a given molecule (when rate constancy is not rejected); this is common practice to deal with molecules that do not fit the clock model across a cladogram (following Takezaki et al. 1995). The linear accumulation of transversions was assumed, and transitions were removed in all analyses because they never met rate constancy. The resulting cladograms from likelihood, parsimony and neighbour-joining analyses are not provided. The authors instead used a previous tree (Farias et al. 1999, 2000) on which to map divergence dates. Curiously, the divergence dates mapped onto this phylogeny do not correspond with the sequence of those divergences (i.e. older divergences are sometimes given more recent divergence dates than recent divergences).

An earlier molecular clock-based analysis (Kumazawa et al. 2000) using mitochondrial genes NADH dehydrogenase subunit 2 and cytochrome $b$ supported a vicariance scenario for cichlid distributions. Only six cichlid species were used in the study (three each from Africa and South America) and 15 species total. The authors concluded that Neotropical and African cichlids had separated from 
each other between 80 and $120 \mathrm{Ma}$, fitting the vicariance model. Their clock was calibrated upon palaeontological and molecular data, based on the assumption that cichlids could not disperse across a marine barrier, and that they are Gondwanan in origin. Unfortunately 95\% confidence intervals were not given, therefore it is unclear how strongly their evidence supports vicariance. For a discussion on the imprecise nature of some molecular clocks and their confidence limits, see Hillis et al. (1996) and Lundberg (1998).

\section{India-Madagascar sister relationship}

With the exception of a few problematic studies discussed above, all analyses recover all Gondwanan groups as monophyletic except Madagascar. Madagascar contains the cichlid taxa that are sister to the remaining cichlids. The three Indian cichlids appear nested within the Malagasy clade whenever Madagascar is adequately sampled (Stiassny et al. 2001; Sparks 2003), making for a monophyletic India-Madagascar group.

\section{Geological history}

A landmass composed of Madagascar and India was isolated following the breakup of Gondwana in the Mesozoic, with a later separation of Madagascar from India approximately $88 \mathrm{Ma}$ (Segoufin and Patriat 1981; Storey et al. 1995; Hay et al. 1999 referred in McCall 1997). Cretaceous deposits on Madagascar lack any cichlid fossils (Gottfried and Krause 1994, 1998). A number of currently wellrepresented endemic vertebrate taxa are also absent from the fossil record of Madagascar, leading some to argue that a recent (Cenozoic) colonization via dispersal took place (Gottfried and Krause 1994, 1998; Krause et al. 1997).

In this study 'India' refers to the entire Indian subcontinent that includes Sri Lanka and adjacent areas. Two cichlid species are native to Sri Lanka, Etroplus maculatus and E. suratenis (Lundberg 1993). Sri Lanka is separated from India by the Palk Strait, which at its narrowest is a mere $19 \mathrm{~km}$ (Pethiyagoda 1991). It is a continental island part of the Indian plate, and may have separated from India during the Early Cretaceous. It is hypothesized that the island was submerged during the Paleocene and Miocene, meaning that the fauna on the island is composed of recent (post-Miocene) invaders. Some of these invasions may have occurred overland via freshwater channels. A landbridge $170 \mathrm{~km}$ wide has been proposed during a period of low sea level during the last glacial period, 15 000-20,000 years ago (Cooray 1984 referred in Pethiyagoda 1991).

\section{Vicariance}

Sparks (2001) states that 'Certainly the most compelling evidence in favor of vicariance and a more ancient age of origin for cichlids than fossils currently establish, is the...monophyletic MalagasySouth Asian assemblage'. This assemblage carries the strongest corroborated relationship between cichlids (Cichocki 1976; Oliver 1984; Stiassny 1991; Farias et al. 1999; Stiassny et al. 2001; Sparks 2003). This relationship appears in every well-sampled analysis (those that include Etroplus and Paretroplus).

The timing of the breakup of India and Madagascar is reported to be $88 \mathrm{Ma}$ (Rabinowitz et al. 1983; Storey et al. 1995) implying that the ancestor of the Indo-Malagasy clade was present before this time. This scenario (if correct) dates the cichlid origin before the end of the Cretaceous. This relationship is also congruent with both prevailing hypotheses of Gondwanan fragmentation. The Hay et al. reconstruction predicts an African sister relationship to the rest of the continental fragments, because it occurred first, with a break between India and Madagascar occurring later (Fig. 5a is the only cladogram of cichlid relationships congruent with the Hay et al. scenario). The classical reconstruction requires a rift between India-Madagascar and Africa-South America, followed by a rifting between Africa and South America and finally between Madagascar and India (Fig. 5c best exemplifies this scheme, 5b, d, f and $g$ are congruent).

\section{The Greater Antilles}

The relationships of the Greater Antillean cichlid fauna are important because the Antilles are not geologically Gondawanan in origin, although they may have in various times of their history been connected to Gondwanan fragments (Rosen 1975, 1985). Croizat's (1962) metaphor of vicariance biogeography being like reconstructing a pane of glass that has been repeatedly shattered seems particularly relevant to the Greater Antilles.

Geologically speaking, the Greater Antilles rest upon a small plate located between the much larger North America, South American and Cocos and 
Nazca plates. The Caribbean plate itself can be divided into a series of minor plates that have separated and merged at various times in their history (Perfit and Williams 1989). Despite their history and position on a tectonic plate, these islands are commonly referred to as 'oceanic.' This nomenclature, like 'secondary freshwater', assumes a priori that overwater dispersal is the only mechanism for organisms to populate these islands. Paulay (1994) defined oceanic islands as islands that have never been connected to a mainland continent and therefore are populated solely by dispersal. Given recent tectonic reconstructions of this area, this definition does not fit the Greater Antilles.

\section{Antillean cichlids}

There are five known cichlids from the Antilles, Cichlasoma tetracanthus, C. ramsdeni, C. haitiensis, C. vombergi and C. woodringi (see Myers 1928 and Darlington 1957 for discussion on other possible species, and distributions). The first two are restricted to Cuba, and the others to Hispaniola. The fossil C. woodringi is either Upper or Middle Miocene (23 to $5 \mathrm{Ma}$ ) in age (Myers 1928; Rivas 1986). Van Couvering (1982) called the fossil '?Pliocene' without explanation in her text while it remained Miocene in her figures. This younger age has been cited by later authors without additional explanation (Casciotta and Arratia 1993; Murray 2001b). This fossil has the notoriety of being the only known freshwater fossil from the Antilles (Burgess and Franz 1989). Bussing (1985) and Rivas (personal communication in Burgess and Franz 1989) comment that this fossil is indistinguishable from C. haitiensis, an extant Hispaniolan species. The Antillean cichlids are often referred to as being in the genus Nandopsis because some authors choose to raise members of the Cichlasoma sections as modified by Miller $(1966,1976)$ to the rank of genus.

A number of authors have stated that Cuba, particularly its eastern half, was once united with Hispaniola in the early history of the Caribbean (Perfit and Williams 1989; Williams 1989). According to Pitman et al. (1993), Cuba and Hispaniola did not separate until a shearing in the late Middle Eocene. Nearly $90 \%$ of the 71 species of Antillean freshwater fishes occur on Cuba and Hispaniola (Burgess and Franz 1989). Sixty-five of these are endemic to an island or island group (Burgess and
Franz 1989). Surprisingly, Puerto Rico, the fourth largest Antillean island, separated from Hispaniola by only the narrow Mona Passage $(130 \mathrm{~km})$, is completely lacking in native freshwater fishes. Puerto Rico does have available habitats, as an introduced African cichlid and many other introduced species maintain populations there (Burgess and Franz 1989). Fishes dispersing from Central or South America would also probably reach Jamaica or the lower Antilles first because of their location (Fig. 8). There are no cichlids on Jamaica (it does have six other native freshwater species), and there are only two native freshwater fishes on the entire Lesser Antilles.

The genus Cichlasoma (sensu lato), to which all the Antillean cichlids belong, dominates the Central American cichlid fauna (75 of about 100 or more species) (Miller 1966, 1976; Kullander 1983, 1998; Roe et al. 1997; Martin and Bermingham 1998). This genus is also found in South America and north to Texas, but its diversity in Central America is unmatched (Bussing 1985).

\section{Phylogenetic relationships}

To date no formal phylogenetic analysis has included the Cuban and Hispaniolan species with Central American and South American species (P. Chakrabarty, in preparation). Rosen (1975) presented a cladogram that had a sister relationship between Central America and the Antillean cichlid fauna, however it included only the Central American and Antillean fauna. This four-taxon cladogram was cited using a "personal communication' from Cichocki who did not include this analysis in any published material or in his dissertation. Without a phylogenetic diagnosis, we lack a measure for selecting between alternative mechanisms for explaining this disjunct distribution.

Myers (1938, 1966; see also Darlington 1957) hypothesized that the freshwater fishes of the West Indies dispersed from Central America, mainly because of the salt tolerance of these 'secondary freshwater fishes'. Myers incorrectly believed the islands formed in situ without connection to other landmasses. Cichlids were lumped into this category of being 'secondarily freshwater' based solely on their occurrence on islands. Rivas (1986) noted that the native cichlids on Cuba and Hispaniola are known only from landlocked freshwater habitats, never brackish or marine habitats. Bussing (1985) 


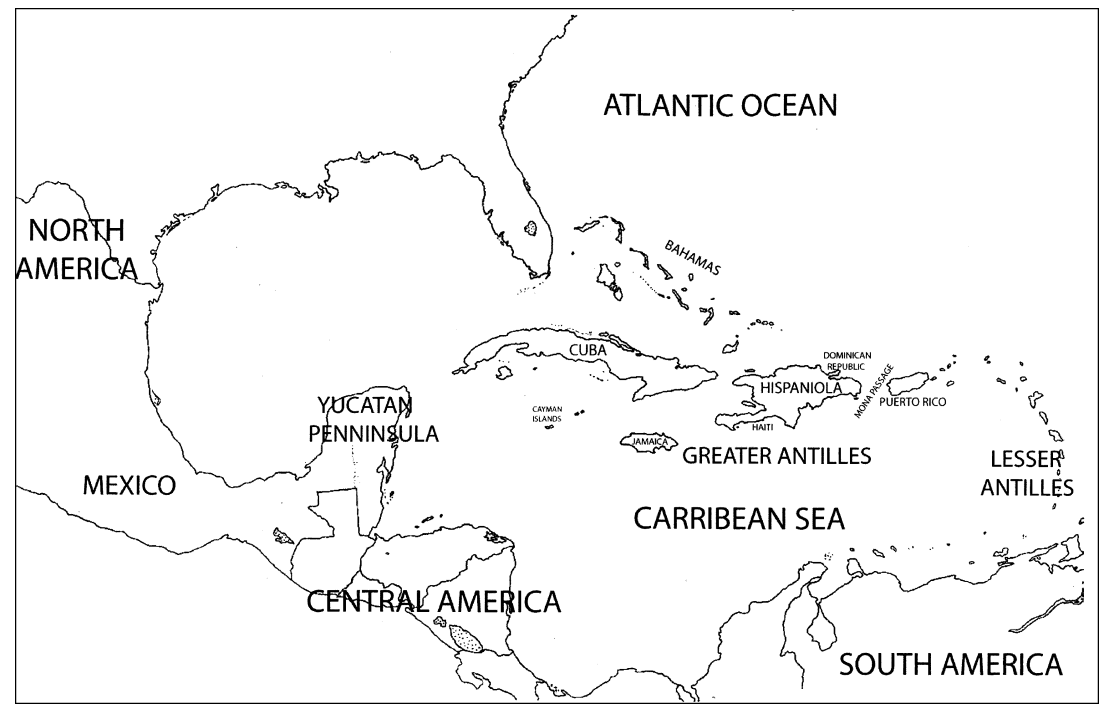

Figure 8 Map of Caribbean region and adjacent areas.

and Martin and Bermingham (1998) hypothesize that South American and Central American cichlids may have dispersed around the continental landmasses by migrating along coastlines, pointing again to salt tolerance in these cichlids. Kullander (1983) gives the only mention of Neotropical cichlids being caught in brackish water. Endemism of cichlid species on Cuba and Hispaniola implies that either (i) they speciated there, presumably long ago, (ii) there have been no successful dispersal events from mainland to island or from island to island, or (iii) extinctions have left this pattern of endemism (so called 'reciprocal monophyly').

Based on his vicariance model, Rosen (1975) gave a Mesozoic minimum age to the freshwater fish fauna of the Antilles including cichlids, atherinids (silversides), poeciliids and other Cyprinodontiformes, synbranchid eels and gars. Rauchenberger (1988) attempted to create a composite area cladogram from 12 other cladograms using these taxa to support Rosen's vicariance model. Most of the trees she used in her analysis are poorly resolved (the cichlid area cladogram she used is an uninformative polytomy), as she notes herself. Only the Gambusia tree (a poeciliid) provided much resolution to her composite. Unfortunately the Gambusia tree she cites (but does not show) from Fink (1971a,b ignores some key elements of the original cladogram (W. L. Fink, personal communication). Her analysis also included only one South American species, which, because of its placement at the base of the cladogram, did not affect the composite tree. It is not surprising then that she found a close relationship between the Antillean and Central American taxa (the only possibility, given her sampling).

\section{The Middle East, Europe and adjacent areas}

There has been little work on the cichlids of this area. The only phylogenetic hypotheses that include species that belong to northern Africa, and the areas adjacent (including the Middle East) are by Klett and Meyer (2002) and Trewavas (1983) (Fig. 9).

\section{Current distribution and sister relations}

Iranocichla hormuzensis Coad 1982 is the only cichlid endemic to Iran and is disjunct from other cichlid populations. Coad (1982) described this species as a relict of a larger cichlid distribution that crossed the Arabian Peninsula. He notes several periods where dispersal across the Arabian Peninsula could be possible over freshwater corridors during dry periods in the Pliocene or Pleistocene (see Kosswig 1965, 1973; Banister and Clarke 1977). Trewavas (1983) believed this species to be the sister to the Ethiopian Danakilia franchettii and noted that perhaps the genera should be synonomized. Trewavas (1983) mentions a cyprinodont in the Red Sea that may also be a relict of a once more widely distributed freshwater group.

Klett and Myer (2002) found that Iranocichla may be the sister taxon to Sarotherodon or Stomatepia, 
both tilapiines in the Sarotherodon group. The Sarotherodon group includes a number of middle eastern and northern African species and may be monophyletic, although the entire tilapiine tribe that they belong to may not (Klett and Myer 2002).

Tristramella magdalenae is a tilapiine found in Syria (Coad 1982; Trewavas 1983) that may also be closely related to Danakilia franchettii (Trewavas 1983). Tristramella simonis is known from Israel and is sister to the African Sarotherodon occidentalis (Klett and Myer 2002).

Loiselle (1985) notes how a number of species from the Nile basin have ranges that extend to the areas around the Persian Gulf including the tilapiines Tilapia zillii, Sorotherodon galilaeus and $S$. aureus. He suggested that this might be evidence for a recent dispersal from Africa to the Middle East during a period of warmer, wetter climates.

\section{Fossils from the area}

Cichlids are absent from the Arabian Peninsula, despite being found in the surrounding areas. This absence may be more the result of a current desert barrier than to a marine barrier. Fossil cichlids in the Middle East listed by Murray (2001b) include two Pliocene cichlids in Israel and at least three lineages of Oligocene Saudi Arabian cichlids. There is some speculation that one of the two Israeli cichlid fossils resembles T. zillii (Murray 2001b). Van Couvering (1982) had earlier speculated on the relationships of one of these fossils and placed it in the genus Tilapia and aligned it with an African Tilapia fossil.

Brown (1970 in Trewavas 1983) describes what he thinks to be a tilapiine cichlid from the Miocene or Oligocene of Saudi Arabia. Perhaps this species was a holdout from before the formation of the Arabian Desert in the Pliocene or Pleistocene.

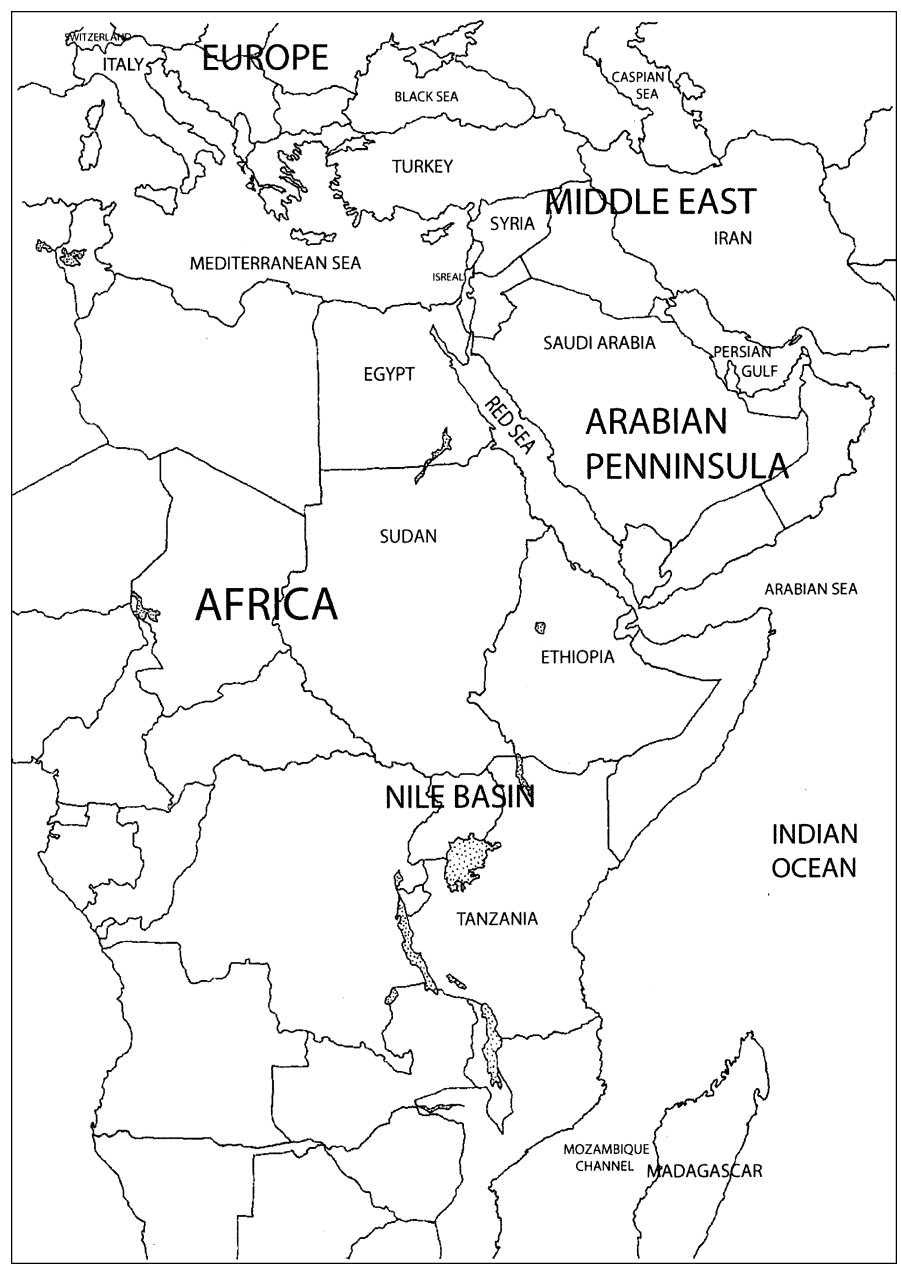

Figure 9 Map of relevant European, Middle Eastern and African areas. 
An Italian fossil from the Eocene has been reported but is highly suspect (Murray 2001). Miocene fossils from Italy, Germany, Moravia and Switzerland are known and may be tilapiines (Gaemers 1989; Murray 2001b). As there is a land connection from northern Africa to Arabia and Europe, dispersal by freshwater routes overland is quite plausible for this area.

\section{The global cichlid fossil record}

The absence of fossils from the Mesozoic is a point that is often raised against a vicariance hypothesis of cichlid biogeography (Lundberg 1993; Murray 2001b). However, 'absence of evidence is not evidence for absence' (Maisey 1993), particularly given the rarity of Cretaceous freshwater deposits (Patterson 1993). The cichlid fossil record does not falsify hypotheses of vicariance. There are no fossils from extant geological lineages (e.g. African) found on continents other than the ones they are found today. No fossil cichlid from any geographical lineage predates proposed vicariance events. Presence of such fossils would favour pre-drift intercontinental speciation over vicariance (Lundberg 1993) (see Fig. 7b-2).

\section{Minimum ages}

Murray (2000a, 2001a) has described the oldest known fossil cichlids, which are from the Eocene of Tanzania. These fossils establish the minimum age of cichlids to be 45 million years old. Before Murray's (2000a) descriptions, the oldest fossil cichlids were from the Oligocene (23-34 Ma) (Van Couvering 1982; see also Greenwood 1989). Murray has placed these cichlids in a derived position among African cichlids, sister to Hemichromines, based on predorsal spine count and squamation (Murray 2001, 2001b). Sparks (2003) also noted that these fossils appear to be more derived than either Heterochromis or Tylochromis (the least derived African cichlids) and thought they were closely related to modern haplochromines or hemichromines. He comments that if cichlids from the Eocene seem morphologically indistinguishable from extant forms, then cichlids are likely a much older group than the fossils imply.

Fossil cichlids are also known from the Miocene of South America (Casciotta and Arratia 1993). Stewart (2001) lists all African cichlid fossils of
Neogene Africa; these fossils are also reported to have modern morphologies (Stiassny 1991).

\section{The acanthomorph record}

Some authors challenge a mid-Cretaceous (approximately $120 \mathrm{Ma}$ ) origin for Cichlidae (Lundberg 1993), because of their derived position on the tree of acanthomorphs and the minimum age suggested by the fossil record (Fig. 10). The absence of cichlids of a Cretaceous age becomes pivotal when their phylogenetic position is taken into account. The derived position of cichlids within acanthomorphs means that for cichlids to be Cretaceous all other less derived acanthomorphs must also be Cretaceous.

There are many actinopterygians (ray finned fishes) in the global Mesozoic fossil record, but no acanthomorphs (spiny-rayed teleosts) until the Late Cretaceous (approximately 75-65 Ma). Lundberg (1993) considered this evidence that acanthomorphs did not yet exist. If fossils provide the minimum age of taxa, cichlids are at least Eocene (Murray 2001); the Labroidei, early Cenozoic (younger than $65 \mathrm{Ma}$ ) (Carroll 1988); Percomorpha, possibly Late Cretaceous but the earliest unquestionable perciformes are early Cenozoic (after $65 \mathrm{Ma}$; Patterson 1993); and acanthomorphs are early Late Cretaceous (Patterson 1990, Patterson 1994). Percomorpha appear 20-25 Myr after the first acanthomorphs in the fossil record (Murray 2001).

Higher acanthomorph diversity is not recorded in fossils until the Late Paleocene/Early Eocene, at which time there appears to be a major radiation (Fig. 10) (Patterson 1993, 1994). Acanthomorphs include 15000 species in 280-300 families (Patterson 1993, 1994). There are 9000 Perciformes species within 150-230 families (Nelson 1984; Patterson 1994). The fossil record suggests that the majority of Perciform diversity, including cichlids, radiated in the Eocene. The possibility of a gap in the fossil record for acanthomorphs between the Late Cretaceous and Paleocene has been proposed (Patterson 1993; Sparks 2001). However, there is little evidence for the gap being due to anything besides their actual absence, particularly in the face of the abundance of Actinopterygian fossils from freshwater deposits of this time. Only the discovery of new fossils and deposits from this period will resolve this question. 

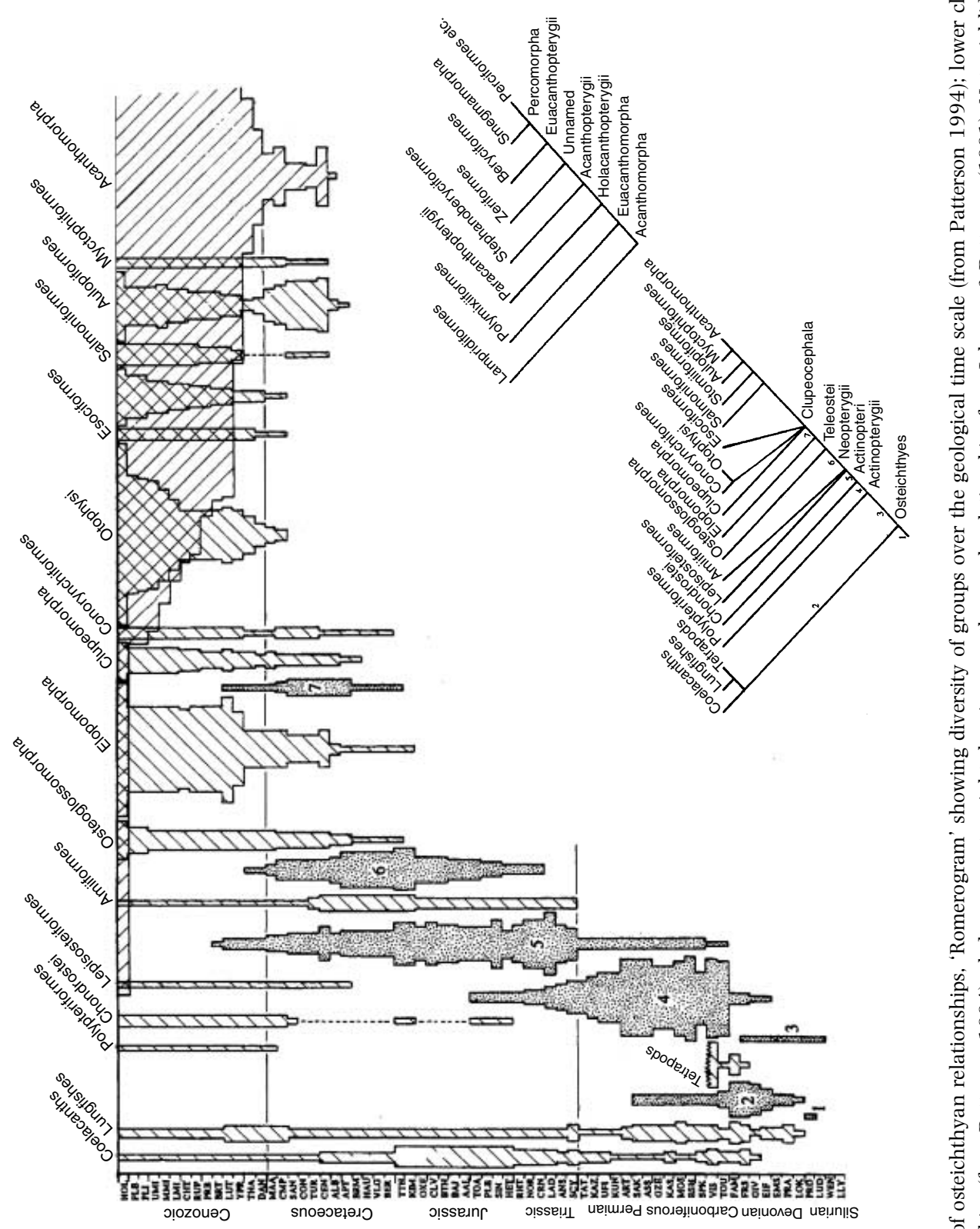

$\dddot{\mathscr{F}}$

बे

ริ

氖

Е

토

迄

卷

क

苯

를

을

응

$\stackrel{5}{\square}$

वे

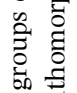

○苞

도.

营

$\Rightarrow$ 要

bo क क

空

के 을

효

颉

용

छี क्ष

은

苛

ฮิ ป

릉.

造

छ

吾

氖

के

등 节

空。气

离 


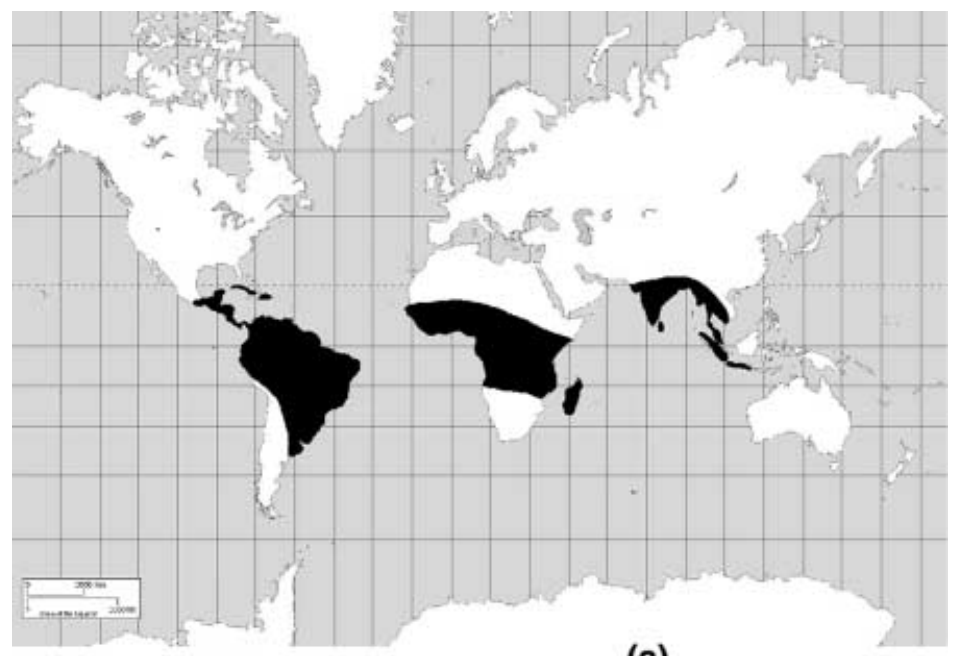

(a)

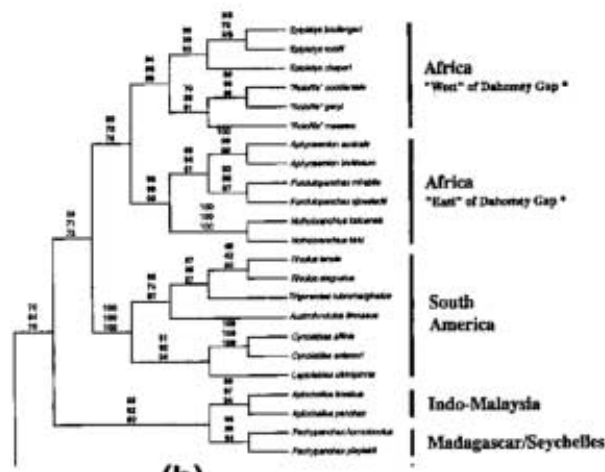

(b)

Figure 11 (a) Map of worldwide distribution.of the Aplocheiloidei and (b) Phylogenetic hypothesis from Murphy \& Collier using three mitochondrial genes and parsimony.

\section{Discussion}

This paper has reviewed all prior phylogenetic hypotheses that have implications about cichlid biogeographical hypotheses. Cladograms by a number of authors (Cichocki 1976; Zardoya et al. 1996; Streelman et al. 1998; Farias et al. 1999, 2000; Schliewen and Stiassny 2003; Sparks 2003) recover monophyletic Gondwanan lineages (Africa, South America, India-Madagascar) and do not refute a vicariance scenario for explaining cichlid distributions. The well-supported relationships within cichlids show a convincing vicariance pattern reflecting Gondwanan fragmentation. Sparks' (2001) combined mitochondrial gene and morphological evidence tree is the only analysis to date that recovers a topology that follows the proposed sequence of fragmentation by Hay et al. (1999). Notably at deep nodes this tree is weakly supported (presumably because of the use of quickly evolving mitochondrial genes), both by Bremer support $(<2)$ and Jackknife resampling $(<50)$ values in clades showing sister lineages between the Neotropics and IndiaMadagascar.

The use of slower evolving nuclear fragments TmoM27 and Tmo4C4 in phylogenies analysing worldwide cichlid distributions provides congruent results (Fig. 5b-f) that support the classical reconstruction of Gondwanan fragmentation. The evidence provided by these cladograms is important, but their faults (including excluding some phylogenetically important taxa) must be noted and avoided in future studies.

The introductory section of this paper identified four potential falsifiers of vicariance. The first (when phylogenetic patterns do not follow the sequence of divergence of known geological processes) is found in the paraphyletic groups shown in Fig. 6. In all 
these trees, one of the three noted 'problematic taxa' breaks up what are otherwise monophyletic groups. This can be interpreted as either evidence for dispersal for these species, or that the nature of the characters in these species is difficult to code in phylogenetic analyses. An alternative to either strict dispersal or miscoding is that these species are part of a pre-rifting divergence of lineages. The paraphyletic groups in the cladograms in Fig. 6 may be evidence for the pre-drift expansion of the distributions for the ancestors of $H$. multidens, O. polleni and Chaetobranchopsis australis into other Gondwanan fragments followed by isolation of these three particular species by fragmentation. None of the cladograms with paraphyletic groups are found in more than one analysis. Independent evidence never supported any of these trees. As given in Figure 6a, Streelman and Karl (1997) and Streelman et al. (1998) both found Oxylapia sister to the Neotropics. However, this appears to be the same analysis with only a few differences in ingroup and outgroup sampling.

The other falsifiers listed earlier are not found in any tree previously published. No cichlid lineage is shown to be younger than vicariant events from phylogenetic analyses. No cichlid species has a distribution on either side of a supposed barrier to dispersal, outside of introduced species. The two molecular clock analyses (Kumazawa et al. 2000; Vences et al. 2001) have many problems (see 'Molecular clock evidence') and therefore should not be considered falsifiers of vicariance or dispersal.

Some readers may disagree with using parsimony as grounds to favour a particular hypothesis of biogeography. There are several possible explanations for the presented evidence of monophyly on Gondwanan fragments regardless of ones philosophical standpoint. Lundberg (1993) discusses four possible interpretations for disjunct monophyletic distributions that are modified here for the Gondwanan cichlid case: (1) simple drift vicariance: ancestral distribution was Gondwanan, and the origins of separate clades were facilitated by the separation of the Gondwanan fragments. (2) Predrift intercontinental speciation: separate lineages originated on Gondwana, or extinction on separated fragments post-drift led to the same pattern (reciprocal monophyly). (3) Post-drift dispersal: unique overwater dispersal from one fragment to the other of a single species following the break-up of Gondwana, and lineages arising from it. (4) Indirect dispersal pathways: a now extinct marine cichlid species (or several species from one clade), gave rise to independent freshwater lineages in different Gondwanan fragments via dispersal.

This review finds that drift vicariance (conclusion 1 ) is the most favoured conclusion because of a lack of support for the alternatives. Cladograms that would have supported conclusion 2 would be similar to hypothetical cladogram $7 \mathrm{~b}$, because free dispersal across Gondwana would have left multiple paraphyletic groups. This scenario then would require extinctions of all lineages save for one on each Gondwanan fragment. There is no evidence for this pattern of extinctions. All cichlid fossils thus far collected belong to extant lineages on their respective fragments.

Post-drift dispersal (conclusion 3) would require one species to give rise to the entire continental fauna on each Gondwanan fragment (and not on any Laurasian fragments). Although there is always a possibility of dispersal occurring in this way, there is no evidence for only one successful dispersal event having occurred between continents followed by extinction of the founder species.

Conclusion 4 considers that a widely spread, now extinct marine ancestor might have given rise to all the extant freshwater lineages. This possibility as pointed out by Lundberg (1993) is intriguing because it would explain the absence of Mesozoic cichlid fossils. It would also allow for the minimum age of cichlids to be corroborated by both their fossil record and their distribution. If there were a marine ancestor that gave rise to monophyletic cichlid groups on separate Gondwanan fragments the phylogenetic pattern that would be predicted would be a polytomy. This pattern is not found in any phylogenetic analysis and should therefore be ruled out.

For vicariance to be the simplest conclusion of the evidence, other non-cichlid taxa must also show the repeated phylogenetic pattern. Figure 11 shows the worldwide distribution of aplocheiloid killifish. These fishes have a very similar worldwide distribution, and a congruent phylogeny with Cichlidae (Murphy and Collier 1997). The aplocheiloid phylogeny shows a sequence of divergence fitting the classic reconstruction of fragmentation (cladograms 5b-e). Sparks (2001) has noted a number of groups that have sister relationships between Madagascar and South America and/or India rather than with Africa, supporting the Hay et al. reconstruction; these are also congruent with his most parsimonious tree (Fig. 5a). These include boid snakes (Kluge 1991), notosuchid and peirosaurid crocodiles 
(Buckley and Brochu 1999), pelobatid frogs (Titus and Frost 1996) and pelomedusid turtles (Noonan 2000). Groups that share the South AmericanAfrican connection (that are also on other southern landmasses) supporting the classic view of vicariance include lungfish, osteoglossiforms, nandids, galaxiids, synbranchids and some cyprinodontiforms (Rosen 1975; Lundberg 1993; Lundberg et al. 2000). As of now there is no reasonable way to distinguish between the alternative geological views of Gondwana fragmentation using cichlids, because a robust phylogeny containing all fragments is still lacking.

The Greater Antillean cichlid fauna is clearly an area of future study that requires a well-supported phylogeny to distinguish between alternative biogeographical hypotheses. Studies that recover paraphyletic connections between the islands and neighbouring continents, or with species that are commonly found in marine waters, may favour dispersal. Cladograms for non-cichlid taxa already exist supporting several vicariance alternatives as well as dispersal (Fink 1971a,b; Murphy and Collier 1996; Iturralde-Vinent and MacPhee 1999; Lydeard et al. 2002; references in Burgess and Franz 1989).

The relationships of European fossil cichlids and extant and extinct Middle Eastern cichlids seem to point to North African lineages (Trewavas 1983; Klett and Myer 2002). The presence of cichlids in these areas can be explained by freshwater connections overland.

The relationship between India (Etroplus) and Madagascar (Paretroplus) is the most highly corroborated sister relationship between two now separated Gondwanan fragments. If a dispersalist explanation is used to explain this relationship then cichlids were able to successfully disperse between Madagascar and India across the Indian Ocean but not from Madagascar to Africa across the narrow (430 km) Mozambique Channel. The unlikeness of this scenario makes a strong case against a dispersalist hypothesis that explains the distribution of the Cichlidae. This pattern of relationships (Madagascar to/from India rather than to Africa) is congruent with the area cladograms of other Malagasy freshwater fishes including several atherinoid families, aplocheilelid genera, pellonuline clupeid genera and perhaps some members of the Gobiidae (Sparks 2001).

Future fossil discoveries will have important consequences for cichlid biogeography. Cichlid fossils from the Cretaceous, that are congruent with a particular reconstruction of Gondwanan break up, would be the final piece of the puzzle supporting a drift vicariance scenario for cichlid distributions. An Antarctic cichlid fossil would mean that cichlids were on this landmass before it became inhospitable to freshwater fishes in the Tertiary (Nelson 1984). Such a discovery would support a Hay et al. (1999) reconstruction because it would provide a relatively recent connection between South America and Madagascar.

Given what is currently known about cichlid relationships, vicariance cannot be ruled out in favour of dispersal. Alternative global reconstructions will require more robust phylogenies with greater taxonomic sampling (including the Antilles and the Middle East) that can identify higher-level relationships and shed light on alternative biogeographical hypotheses.

\section{Acknowledgements}

I would like to thank the following individuals for suggestions on prior versions of this manuscript: John Sparks, Bill Fink, Doug Futuyma, Heok Hee Ng, Rick Lehtinen, Jeff Wilson, Ron Oldfield, Josh Rest, Pricilla Tucker, Earl Werner, Melanie Stiassny, Michael Reiskind and two anonymous reviewers. Also thanks for useful comments and debate from Leo Smith, Bob Schelly, Jerry Smith and the systematics discussion group at the UMMZ. Many thanks also to Annemarie Noël for help with illustrations.

\section{References}

Avise, J.C., Arnold, J., Ball, R.M. Jr et al. (1987) Intraspecific phylogeography: the mitochondrial DNA bridge between population genetics and systematics. Annual Review of Ecology and Systematics 18, 489-522.

Banister, K.E. and Clarke, M.A. (1977) The freshwater fishes of the Arabian Peninsula. Journal of Oman Studies, Special Report (Scientific Results of the Oman Flora and Fauna Survey), 111-154.

Barlow, G.W. (2000) The Cichlid Fishes: Nature's Grand Experiment in Evolution. Perseus Publishing, Cambridge.

Barron, E.J. (1987) Cretaceous plate tectonic reconstructions. Paleogeography, Paleoclimatology, Palaeoecology 59, 3-29.

Briden, J.C., Dewry, G.C. and Smith, A.G. (1974) Phanerozoic equal area world maps. Journal of Geology $\mathbf{8 2}$, 555-574.

Briggs, J.C. (1984) Freshwater fishes and biogeography of Central America and the Antilles. Systematic Zoology 33 , 428-435. 
Buckley, G.A. and Brochu, C.A. (1999) An enigmatic new crocodile from the upper Cretaceous of Madagascar. Special Papers in Paleontology 60, 149-175.

Burgess, G.H. and Franz, R. (1989) Zoogeography of the Antillean freshwater fish fauna. In: Biogeography of the West Indies: Past, Present, and Future. (ed. C.A. Woods). Sandhill Crane Press, Gainesville, pp. 263-304.

Bussing, W.A. (1985) Patterns of distribution of the Central American ichthyofauna. In: The Great American Biotic Interchange (eds F.G. Stehli and S.D. Webb). Plenum, New York, pp. 453-473.

Carroll, R.L. (1988) Vertebrate Paleontology and Evolution. W.H. Freeman, New York.

Casciotta, J. and Arratia, G. (1993) Tertiary cichlid fishes from Argentina and reassessment of the phylogeny of New World cichlids (Perciformes: Labroidei). Kaupia Darmstädter Beiträge zur Naturgeschichte 2, 195-240.

Cichocki, F.P. (1976) Cladistic History of Cichlid Fishes and Reproductive Strategies of the American Genera Acarichthys, Biotodoma, and Geophagus. Vol. 1. Unpublished PhD Dissertation, The University of Michigan, Ann Arbor.

Coad, B.W. (1982) A new genus and species of cichlid endemic to Southern Iran. Copeia 1982, 28-37.

Cooray, P.G. (1984) An Introduction to the Geology of Sri Lanka (Ceylon). National Museum of Sri Lanka, Colombo.

Crisci, J.V. (2001) The voice of historical biogeography. Journal of Biogeography 28, 157-168.

Croizat, L. (1962) Space, Time, Form: The Biological Synthesis. Published by the author, Caracus.

Croizat, L., Nelson, G. and Rosen, D.E. (1974) Centers of origin and related concepts. Systematic Zoology 23, 265287.

Darlington, P.J. Jr. (1957) Zoogeography: The Geographical Distribution of Animals. Chapman \& Hall, London.

Dietz, R.S. and Holden, J.C. (1970) The beak-up of Pangea. Scientific American 223, 30-41.

Farias, I.P., Ortí, G., Sampaio, I., Schneider, H. and Meyer, A. (1999) Mitochondrial DNA phylogeny of the family Cichlidae: monophyly and fast molecular evolution of the Neotropical assemblage. Journal of Molecular Evolution 48, 703-711.

Farias, I.P., Ortí, G. and Meyer, A. (2000) Total evidence: molecules, morphology, and the phylogenetics of cichlid fishes. Journal of Experimental Zoology (Mol. Dev. Evol.) 288, 76-92.

Fink, W.L. (1971a) A revision of the Gambusia puncticulata complex (Pisces: Poeciliidae). Publications of the Gulf Coast Research Laboratory Museum 2, 11-46.

Fink, W.L. (1971b) A revision of the Gambusia nicaraguensis species group (Pisces: Poeciliidae). Publications of the Gulf Coast Research Laboratory Museum 2, 47-77.

Fryer, G. (2001) On the age and origin of the species flock of haplochromine cichlid fishes of Lake Victoria. Proceedings of the Royal Society, London B 268, 1147-1152.

Gaemers, P.A.M. (1984) Taxonomic position of the Cichlidae (Pisces, Perciformes) as demonstrated by the morphology of their otoliths. Netherlands Journal of Zoology 34, 566-595.

Gaemers, P.A.M. (1989) The first cichlids (Perciformes, Pisces) from Europe: the new, fossil genus Europotilapia, evidence from otoliths and teeth. Annals du Muséum Royal d'Afrique Centrale, Sciences Zoologiques 257, 109116.

Gottfried, M.D. and Krause, D.W. (1994) Late Cretaceous fishes from Madagascar: a first look. Journal of Vertebrate Paleontology 14 (Suppl.), 26A.

Gottfried, M.D. and Krause, D.W. (1998) First record of gars (Lepisosteidae, Actinopterygii) on Madagascar: Late Cretaceous remains from the Mahajanga Basin. Journal of Vertebrate Paleontology 18, 275-279.

Grant, W.S. and Leslie, R.W. (2001) Inter-ocean dispersal is an important mechanism in the zoogeography of hakes (Pisces: Merluccius spp.). Journal of Biogeography 28, 699-721.

Greenwood, P.H. (1989) The haplocromine species (Teleostei, Cichlidae) of the Cunene and certain other Angolan rivers. Bulletin of the British Museum (Natural History) Zoology 47, 187-239.

Hay, W.W., DeConto, R.M., Wold, C.N. et al. (1999) Alternative global Cretaceous paleogeography. In: Evolution of the Cretaceous Ocean-Climate System (eds E. Barrera and C.C. Johnson). Geological Society of America Special Paper 332, Boulder, Colorado, pp. 147.

Hillis, D.M., Mable, B.K. and Moritz, C. (1996) Application of molecular systematics: the state of the field and a look to the future. In: Molecular Systematics (eds D.M. Hillis, C. Moritz and B.K. Mable), 2nd edn. Sinauer Associates, Sunderland, pp. 515-543.

Iturralde-Vinent, M.A. and MacPhee, R.D.E. (1999) Paleogeography of the Caribbean region: implications for Cenozoic biogeography. Bulletin of the American Museum of Natural History 238, 1-95.

Johnson, T.C., Scholz, C.A., Talbot, M.R. et al. (1996) Late Pleistocene desiccation of Lake Victoria and rapid evolution of cichlid fishes. Science 273, 10911093.

Klett, V. and Meyer, A. (2002) What, if anything, is a Tilapia? - Mitochondiral ND2 phylogeny of tilapiines and the evolution of parental care systems in the African Cichlid fishes. Molecular Biology and Evolution 19, 865883.

Kluge, A.G. (1989) A concern for evidence and a phylogenetic hypothesis of relationships among Epicrates (Boidae, Serpentes). Systematic Zoology 38, 7-25.

Kluge, AG. (1991) Boine snake phylogeny and research cycles. Miscellaneous Publications. Museum of Zoology, University of Michigan 178, 1-58.

Kosswig, C. (1965) Zur historischen Zoogeographie der Ichthyofauna im Süsswasser des sudlichen Kleinasiens. Zoologische Jahrbücher für Systematik 92, 8390. 
Kosswig, C. (1973) Über die Ausbreitungswege sogenannter perimediterraner Süsswasserfische. Bonner Zoologische Beiträge 24, 165-177.

Krause, D.W., Hartman, J.H. and Wells, N.A. (1997) Late Cretaceous vertebrates from Madagascar: implications for biotic change in deep time. In: Natural Change and Human Impact in Madagascar (eds S.M. Goodman and B.D. Patterson). Smithsonian Institute Press, Washington, pp. 3-43.

Kullander, S.O. (1983) A revision of the South American Cichlid Genus Cichlasoma (Teleostei: Cichlidae). The Swedish Museum of Natural History, Stockholm.

Kullander, S.O. (1998) A phylogeny and classification of the South American Cichlidae (Teleostei:Perciformes). In: Phylogeny and Classification of Neotropical Fishes (eds L.R. Malabarba, R.E. Reis, R.P. Vari, Z.M. Lucena and C.A.S. Lucena). Edipucrs., Porto Allegre, pp. 461-498.

Kumazawa, Y., Yamaguchi, M. and Nishida, M. (2000) Mitochondrial molecular clocks and the origin of euteleostean biodiversity: familial radiation of perciforms may have predated the Cretaceous/Tertiary boundary. In: The Biology of Biodiversity (ed. M. Kato). Springer-Verlag, Tokyo, pp. 35-52.

Lippitsch, E. (1995) Scale and squamation character polarity and phyletic assessment in the family Cichlidae. Journal of Fish Biology 47, 91-106.

Loiselle, P.V. (1985) The Cichlid Aquarium. Tetra-Press, Melle.

Lundberg, J.G. (1993) Africa-South American freshwater fish clades and continental drift: problems with a paradigm. In: Africa-South American Freshwater Fish Clades and Continental Drift: Problems with a Paradigm. Biological relationships between Africa and South America (ed. P. Goldblatt). Yale University Press, Tokyo, pp. 157199.

Lundberg, J.G. (1998) The temporal context for the diversification of Neotropical fishes. In: Phylogeny and Classification of Neotropical Fishes (eds L.R. Malabarba, R.E. Reis, R.P. Vari, Z.M. Lucena, C.A.S. Lucena). Edipucrs., Porto Allegre, pp. 49-68.

Lundberg, J.G., Kottelat, M., Smith, G.R., Stiassny, M.L.J. and Gill, A.C. (2000) So many fishes, so little time: an overview of recent ichthyological discovery in continental waters. Annals of the Missouri Botanical Garden 87, $26-62$.

Lydeard, C., Wooten, M.C. and Meyer, A. (2002) Molecules, morphology, and area cladograms: a cladistic and biogeographic analysis of Gambusia (Teleostei: Poeciliidae). Systematic Biology 44, 221-236.

McCall, R.A. (1997) Implications of recent geological investigations of the Mozambique Channel for the mammalian colonization of Madagascar. Proceedings of the Royal Society of London B 264, 663-665.

Maisey, J.G. (1993) Tectonics, the Santana lagerstätten, and the implication for late Gondwanan biogeography. In: Biological Relationships between Africa and South
America (ed. P. Goldblatt). Yale University Press, New Haven, pp. 435-454.

Martin, A.P., Bermingham, E. (1998) Systematics and evolution of lower Central American cichlids inferred from analysis of cytochrome b gene sequences. Molecular Phylogenetics and Evolution 9, 192-203.

Meyer, A., Kocher, T.D. and Wilson, A.C. (1991) African fishes. Nature 350, 468.

Meyer, A., Montero, C. and Spreinat, A. (1994) Evolutionary history of the cichlid fish species flocks of the East African great lakes inferred from molecular phylogenetic data. Archiv für Hydrobiologie, Ergebnisse der Limnologie 44, 407-425.

Miller, R.R. (1966) Geographic distributions of Central American freshwater fishes. Copeia 1966, 773-802.

Miller, R.R. (1976) Geographic distributions of Central American freshwater fishes. In: Investigations of the Ichthyofauna of Nicaraguan Lakes (ed. T.B. Thorson). University of Nebraska, Lincoln, pp. 125-156.

Murphy, W.J. and Collier, G.E. (1996) Phylogenetic relationships within the Apocheiloid fish genus Rivulus (Cyprinodontiformes, Rivulidae): implications for Caribbean and Central American biogeography. Molecular Biology and Evolution 13, 642-649.

Murphy, W.J. and Collier, G.E. (1997) A molecular phylogeny of aplocheiloid fishes (Atherinomorpha, Cyprinodontiformes): the role of vicariance and the origins of annualism. Molecular Biology and Evolution 14, 790-799.

Murray, A.M. (2000a) Eocene cichlid fishes from Tanzania, East Africa. Journal of Vertebrate Paleontology 204, 651-664.

Murray, A.M. (2000b) The Palaeozoic, Mesozoic and Early Cenozoic fishes of Africa. Fish and Fisheries 1, 111-145.

Murray, A.M. (2001a) The oldest fossil cichlids (Teleostei: Perciformes): indication of a 45 million-year-old species flock. Proceedings of the Royal Society of London B $\mathbf{2 6 8}$, 679-684.

Murray, A.M. (2001b) The fossil record and biogeography of the Cichlidae (Actinopterygii: Labroidei). Biological Journal of the Linnean Society 74, 517-532.

Myers, G.S. (1928) The existence of cichlid fishes in Santo Domingo. Copeia 1928, 33-36.

Myers, G.S. (1938) Fresh-water fishes and West Indian zoogeography. Annual Report of the Smithsonian Institute 1937, 339-364.

Myers, G.S. (1966) Derivation of the freshwater fish fauna of Central America. Copeia 1966, 766-773.

Nagl, S., Tichy, H., Mayer, W.E., Takezaki, N., Takahata, N. and Klein, J. (2000) The origin and age of haplochromine fishes in Lake Victoria, East Africa. Proceedings of the Royal Society of London B 267, 1049-1061.

Nelson, J.S. (1984) Fishes of the World, 2nd edn. John Wiley and Sons, New York.

Nelson, G. and Platnick, N.I. (1981) Systematics and Biogeography: Cladistics and Vicariance. Columbia University Press, New York. 
Nishida, M. (1991) Lake Tanganyika as an evolutionary reservoir of old lineages of East African cichlid fishes: inferences from allozyme data. Experientia 47, 974979.

Noonan, B.P. (2000) Does the phylogeny of pelomedusoid turtles reflect vicariance due to continental drift? Journal of Biogeography 27, 1245-1249.

Oliver, M.K. (1984) Systematics of African Cichlid Fishes: Determination of the Most Primitive Taxon, and Studies on the Haplochromines of Lake Malawi. Unpublished $\mathrm{PhD}$ dissertation, Yale University.

Patterson, C. (1993) An overview of the early fossil record of acanthomorphs. Bulletin of Marine Science 52, 29-59.

Patterson, C. (1994) Bony fishes. In: Major Features of Vertebrate Evolution (eds D.R. Prothero and R.M. Schoch). Short Courses in Paleontology, Vol. 7, Paleontological Society, University of Tennessee, Knoxville, pp. 57-84.

Paulay, G. (1994) Biodiversity on oceanic islands - its origin and extinction. American Zoologist 34, 134-144.

Perfit, M.R. and Williams, E.E. (1989) Geological constraints and biological retrodictions in the evolution of the Caribbean sea and its islands. In: Biogeography of the West Indies: Past, Present, and Future (ed. C.A. Woods). Sandhill Crane Press, Gainesville, pp. 47-102.

Pethiyagoda, R. (1991) Freshwater Fishes of Sri Lanka. Wildlife Heritage Trust of Sri Lanka, Colombo.

Pitman, W.C. Jr, Cande, S.C., LaBrecque, J. and Pindell, J. (1993) In: Fragmentation of Gondwana: the Separation of Africa from South America. Biological Relationships between Africa and South America (ed. P. Goldblatt). Yale University Press, New Haven, CT, pp. 15-34.

Rabinowitz, P.D., Coffin, M.F. and Falvey, D. (1983) The separation of Madagascar and Africa. Science 220, 67-69.

Rauchenberger, M. (1988) Historical biogeography of poeciliid fishes in the Caribbean. Systematic Zoology 37, 356-365.

Rivas, L.R. (1986) Comments on Briggs (1984): Freshwater fishes and biogeography of Central America and the Antilles. Systematic Zoology 35, 633-639.

Roe, K.R., Conkel, D. and Lydeard, C. (1997) Molecular systematics of Middle American cichlid fishes and the evolution of trophic-types in 'Cichlasoma (Amphilophus)' and 'C. (Thorichthys)'. Molecular Phylogenetics and Evolution 7, 366-376.

Rosen, D.E. (1975) A vicariance model of Caribbean biogeography. Systematic Zoology 24, 431-464.

Rosen, D.E. (1985) Geological hierarchies and biogeographic congruence in the Caribbean. Annals of the Missouri Botanical Garden 72, 636-659.

Savage, J.M. (1982) The enigma of the Central American herpetofauna: dispersal or vicariance? Annals of the Missouri Botanical Garden 69, 464-547.

Schliewen, U.K. and Stiassny, M.L.J. (2003) Etia nguti, a new genus and species of cichlid fish from the River Mamfue, Upper Cross River basin in Cameroon, West-
Central Africa. Ichthyological Explorations of Freshwaters 14, 61-71.

Scotese, C.R. (1991) Jurassic and Cretaceous plate tectonic reconstructions. Palaeogeography, Paleoclimatology, Paleoecology 87, 493-501.

Segoufin, J. and Patriat, P. (1981) Reconstruction de l'Ocean Indien occidental pour les épouques des anomalies M21, M2 \& 34. Paleoposition de Madagascar. Bulletin de la Societe Geologique de France XXIII, 603-607.

Smith, A.G., Briden, J.C. and Drewry, G.E. (1973) Phanerozoic World Maps. Special Papers in Paleontology 12, 1-42.

Sober, E.R. (1988) Reconstructing the Past: Parsimony, Evolution and Inference. Bradford, MIT Press, Cambridge. Sparks, J.S. (2001) Phylogeny and Biogeography of the Malagasy and South Asian Cichlid Fishes (Teleostei: Perciformes: Cichlidae), including a Survey of the Freshwater Fishes of Madagascar. Unpublished doctoral dissertation, University of Michigan, MI.

Sparks, J.S. (2003) Molecular phylogeny of the Malagasy and South Asian cichlids (Teleostei: Perciformes: Cichlidae). Molecular Phylogenetics and Evolution 30, 599-614.

Sparks, J.S. and Reinthal, P.N. (2001) A new species of Ptychochromoides from southeastern Madagascar (Teleostei: Cichlidae), with comments on the monophyly and relationships of the ptychochromine cichlids. Ichthyological Exploration of Freshwaters 12, 115-132.

Stewart, K.M. (2001) The freshwater fish of Neogene Africa (Miocene-Pleistocene): systematics and biogeography. Fish and Fisheries 2, 177-230.

Stiassny, M.L.J. (1991) Phylogenetic interrelationship of the family Cichlidae: An overview. In: Cichlid Fishes. Behavior Ecology and Evolution (ed. M.H.A. Keenlyside). Chapman and Hall, London, pp. 1-31.

Stiassny, M.L.J. and Jensen, J.S. (1987) Labroid intrarelationships revisited: Morphological complexity, key innovations, and the study of comparative diversity. Bulletin of the Museum of Comparative Zoology, Harvard University 151, 269-319.

Stiassny, M.L.J., Chakrabarty, P. and Loiselle, P.V. (2001) Relationship of the Madagascan cichlid genus Paretroplus with description of a new species from the Betsiboka River drainage of Northwest Madagascar. Ichthyological Exploration of Freshwaters 12, 29-40.

Storey, M., Mahoney, J.J., Saunders, A.D., Duncan, R.A., Kelley, S.P. and Coffin, M.F. (1995) Timing of hot spotrelated volcanism and the breakup of Madagascar and India. Science 267, 852-855.

Streelman, J.T. and Karl, S.A. (1997) Reconstructing labroid evolution with single-copy nuclear DNA. Proceedings of the Royal Society of London B 264, 10111020.

Streelman, J.T, Zardoya, R., Meyer, A. and Karl, S.A. (1998) Multilocus phylogeny of cichlid fishes (Pisces: Perciformes): evolutionary comparison of microsatellite and single copy nuclear loci. Molecular Biology and Evolution 15, 798-808. 
Sturmbauer, C., Baric, S., Salzburger, W., Rüber, L. and Verheyen, E. (2001) Lake level fluctuations synchronize genetic divergences of cichlid fishes in African lakes. Molecular Biology and Evolution 18, 144-154.

Sültmann, H., Mayer, W.E., Figueroa, F., Tichy, H. and Klein, J. (1995) Phylogenetic analysis of cichlid fishes using nuclear DNA markers. Molecular Biology and Evolution 12, 1033-1047.

Takezaki, N., Rzhetsky, A. and Nei, M. (1995) Phylogenetic test of the molecular clock and lineralized trees. Molecular Biology and Evolution 12, 823-833.

Titus, T.A. and Frost, D.R. (1996) Molecular homology assessment and phylogeny in the lizard family Opluridae. Molecular Phylogenetics and Evolution 6, 49-62.

Trewavas, E. (1983) Tilapiine Fishes of the Genera Sarotherodon, Oreochromis and Danakilia. British Museum (Natural History), London.

Van Couvering, J.A.H. (1982) Fossil cichlid fishes of Africa. Special Papers in Paleontology, Vol. 29. The Paleontological Association, London.

Vences, M., Freyhof, J., Sonnenberg, R., Kosuch, J. and Veith, M. (2001) Reconciling fossils and molecules:
Cenozoic divergence of cichlid fishes and the biogeography of Madagascar. Journal of Biogeography 28, 10911099.

Williams, E.E. (1989) Old problems and new opportunities in West Indian Biogeography. In: Biogeography of the West Indies: Past, Present, and Future (ed. C.A. Woods). Sandhill Crane Press, Gainesville, pp. 1-46.

pZardoya, R., Vollmer, D.M., Craddock, C., Streelman, J.T., Karl, S. and Meyer, A. (1996) Evolutionary conservation of microsatellite flanking region and their use in resolving the phylogeny of cichlid fishes (Pisces: Perciformes). Proceedings Biological Sciences 263, 15891598.

Zihler, F. (1982) Gross morphology and configuration of digestive tracts of Cichlidae. (Teleostei: Perciformes) phylogenetic and functional significance. Netherlands Journal of Zoology 32, 544-571.

Zonenshain, L.P., Savostin, L.A. and Sedova, P. (1984) Globalinye paleogeodinamicheskie rekonstruktsii dlya posledvich $160 \mathrm{~min}$ let: (Global paleogeodynamic reconstructions of the past 160 million years). Geotektonika 3, $3-16$. 